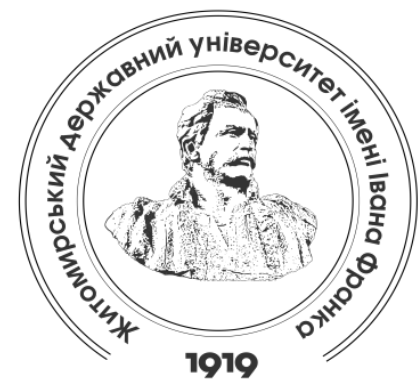

Zhytomyr Ivan Franko State University Journal. Pedagogical Sciences. Vol. 4 (99)

Вісник Житомирського державного університету імені Івана Франка.

Педагогічні науки. Вип. 4 (99)

ISSN (Online): 2664-0155

\title{
UDC 378.15
}

DOI 10.35433/pedagogy.4(99).2019.56-66

\section{INTERACTIVE TRAINING OF FOREIGN MEDICAL STUDENTS FOR VERBAL COMMUNICATION IN THE PROCESS OF LEARNING THE UKRAINIAN LANGUAGE}

\begin{abstract}
N. V. Kalashnik*
The article substantiates the importance of proper mastery of Ukrainian language by foreign medical students in higher education institutions of Ukraine as the means of successfully acquiring the major competences, including the proper verbal and non-verbal communication.

Emphasis is placed on the necessity of using the interactive methods in the educational process, which have received considerable attention in pedagogical science and practice in recent years. It is stated that the combination of reproductive and creative exercises is important in the formation of students' verbal speech communication. Such interactive method as educational game is marked as one of the most effective and widespread in pedagogical practice, including the following: "if I was a teacher", "competitions of experts", "detectives", "deepening of essence", "generalization", "brainstorming", "ask a question", "role embodiment". Within the framework of solving the problem of forming the ability for verbal communication of foreign students' approximate variants of situations that can bring them closer to establishing contacts with native Ukrainian speakers are considered. The importance of controlling the academic achievements of foreign students in the process of mastering linguistic means of communication, based on the principles of science and efficiency, hierarchical organization, objectivity, systematicity, fairness and comprehensiveness is highlighted.
\end{abstract}

Key words: medical student, language means of communication, interactive means of education, educational game-based activities, module-based education, module-rating assessment.

\footnotetext{
${ }^{*}$ Candidate of Pedagogical Science (PhD in Pedagogy), Associate Professor

(Pirogov Vinnytsia National Medical University)

kalashnuknatalia@gmail.com

ORCID: 0000-0001-5312-3280
} 


\section{ІНТЕРАКТИВНА ПІДГОТОВКА ІНОЗЕМНИХ СТУДЕНТІВ-МЕДИКІВ ДО МОВАЕННСВОÏ КОМУНІКАЦІЇ В ПРОЦЕСІ НАВЧАННЯ УКРАЇНСЬКОЇ МОВИ}

\section{H. B. Kasawrik}

у статті обтрунтовано важливість належного оволодіння майбутніми медикамиіноземиями у закладах вищої освіти Украӥни мовними засобами комунікації, в основі чого лежить засвоєння української мови, оскільки показником успішної підготовки зазначених фахівиів є високий рівень оволодіння ними провідними компетентностями, зокрема мовною та мовленнєвою.

Акиентовано на необхідності застосування з иією метою в навчальному проиесі інтерактивних методів, яким останнім часом у педагогічній науиі $i$ практииі приділяеться значна увага. Вказано, шо важливим у формуванні мовленнєвої комунікації студентів є поєднання репродуктивних і творчих вправ. Відзначено як один із найбільш ефективних інтерактивних методів навчальну гру, розкрито сутність поширених у педагогічній практииі ігор, а саме: "якби я був викладачем", "змагання знавиів", "детективи", "поглиблення суті", "узагальнення", "мозковий итурм", постав запитання", "втілення в роль". У межах вирішення завдання сформувати здатність до мовленнєвої комунікаиії студентів-іноземиів розглянуто орієнтовні варіанти ситуацій, які зможуть наблизити їх до встановлення контактів з носіями української мови. Наголошено на важливості контролю навчальних досягнень студентів-іноземиів у проиесі оволодіння мовними засобами комунікаиї̈, побудованому на приниипах науковості й ефективності, ієрархічної організаиії, об'єктивності, систематичності, справедливості й усебічності.

Ключові слова: студент-медик, мовні засоби комунікації, інтерактивні методи навчання, навчально-ігрова діяльність, модульне навчання, модульно-рейтинговий контроль.

Introduction of the issue. Throughout their studies at the institutions of higher education, foreign students learn Ukrainian language, which is necessary for their communication in native speakers. The main task of teachers is to ensure that they have acquired an adequate and appropriate level of linguistic knowledge and communication skills as a component of relative competence required in their further professional activity.

The intensification of the educational process on mastering verbal communication by future professionals is a common issue nowadays. Particular emphasis in solving this problem is placed on the skillful application of a set of interactive teaching methods, including the use of their (students') own capabilities and tools.

Current state of the issue. The study of theoretical and methodological conditions of peculiarities of foreign students' education is viewed in the works of H. Bochev, T. Dementieva, M. Dudchenko, O. Lysako, O. Rezvan, H. Shevchuk, M Shcherbiak and others. The following Ukrainian scientists have dedicated their work to the introduction of interactive technologies in education: I Hryshchenko [1], O Pometun and L. Pyrozhenko [2], N. Lalak [5], T. Peresunko, S. Sysoieva [6]. This issue is widely covered in foreign pedagogy.

Aim of our article is to highlight the possibilities of using interactive teaching methods in order to enhance the process of mastering foreign languages by foreign medical students, including the means of verbal communication.

Research results and discussion. The subject of the study is foreign students, who, in the process of learning Ukrainian as a foreign language, should acquire a complex set 
of professionally-oriented knowledge, skills and abilities necessary for successful fulfillment of their professional duties and complete selfrealization.

An indicator of successful training of the mentioned above specialists is high level of mastery of their leading competencies, linguistic in particular, which includes verbal and non-verbal (speech-based) components. These definitions are of great importance when we focus attention on mastering the professional language.

Linguistic competence is a kind of preamble to the production of utterances in a foreign language and is realized through speech and serves as the theoretical basis of speech through the analysis and synthesis of texts. Content of linguistic competence is the ability to understand and realize the phonetic, lexical and grammatical nature of expression, which is formed on the basis of learning categories and units of language and their functions, studying the laws and rules of mastering the system-structural formations of semantic, syntactic, morphological, phonological origin in order to understand and construct speech patterns, thus, it is the ability to understand and realize the grammatical nature of expression. Professional speech of a medical specialist is a doctor's dialogue with a patient at a polyclinic, hospital, clinic or a communication process between a pharmacist and a customer at a pharmacy, including writing various types of medical documentation: surgery protocol, medical history or abstracts, etc. It is imperative for a healthcare professional to use specific terms of a high level of standardization, significance and accuracy of wording.

Mastering the language and speech is a necessary condition for the formation of a socially active identity, thus, shaping the foreign medical students as competent speakers in
Ukraine depends in many cases on the work of vocabulary teachers during the Ukrainian language lessons.

The productivity of learning vocabulary units and their definitions, as well as their active use in oral and written Ukrainian professional speech largely depends on an appropriate system of preparatory exercises, sequentially aimed at both: translation, thoughtful mastery of terminology and the activation of speaking and listening skills required for the use of a peculiar industry-based terminology in standard and non-standard working situations.

Effective is a combination of exercises of two types: the ones of reproductive nature, which require performing an informative function; and the creative ones, which promote the active independent use of terminological vocabulary in accordance with the professional situation. Among a large number of reproductive exercises, it is efficient to use the following: giving an oral explanation to professional terms in the Ukrainian language; selecting terms to the proposed definitions; compiling a vocabulary to the text from a professional textbook, explaining the terms and featured definitions; retelling the material of the previous lecture, paying attention to the pronunciation and use of professional terminology.

Exercises of creative origin should be more complex and provide greater freedom and independence of the student during their execution, for example: searching for synonymic pair of featured terms with the help of topical vocabulary, making the sentences with them, taking into account the nuances of their meanings; using the dictionary to translate the antonyms and make sentences with them; compiling a vocabulary statement using professional terminology; making a dialogue on a professional topic, saturated with particular professional terminology; reading the text, correcting 
the mistakes and inserting the appropriate terms.

Undoubtedly, the most appropriate for the formation of vocational competence on the basis of scientific and professional terminology is the use of specialty-based texts, which are small in volume, accessible in content, rich in words, persistent phrases and grammatical constructions, which are typical and distinctive for the language studied. Only at the text level the professional terminology investigated functions as a coherent communication system, suitable for use in certain job cases and educational situations.

The language teacher cannot organize the work on the study of professional terminology as a system, which serves as a basis for mastering the future profession, as well as to find informative texts, suitable for a particular profession or to select from a large number of terms the most important and appropriate ones. Thus, according to our point of view, there is a way to solve this burning issue: a close cooperation of professionallyoriented Ukrainian language teachers with teachers of profiling disciplines in the process of development and approbation of the integrated methodological teaching manuals and textbooks, containing a large number of basic knowledge for future specialists with the excessive use of the most used terminological units and constructions, including translation manuals with vocabulary minima of professional terms and professional compounds that would describe professional terminology in the term system, taking into account all generic and logical connections. It would be desirable to teach professionally-oriented disciplines in the state language, in order to increase the number of Ukrainian-language textbooks, industry-specific translation and interpretative dictionaries.

Thus, V. Yukalo [8] in his manual developed a system of exercises and tasks aimed at developing the language culture of the medical students. The "Dictionary of Difficulties of RussianUkrainian Translation" helps students correct common mistakes (especially Russianisms) that are used in doctors' professional "круглодобово/цінодобово";

"алое/алоє"; "синець/синяк", etc. The author paid considerable attention to mastering linguistic stereotypes of doctor's communication, correcting errors in the application of these stereotypes.

("завідувач відділення/ завідуючий відділенням"; "кардіограма/кардіограма серця"), accentuation norms: "прогУАянковий / прогулянкОвий"; "асимЕтрія/асиметрIя" and so on. Such work helps to optimize the process of communication in the field of medicine.

For foreign students we suggest to use English-language texts with medical terminology for translation into Ukrainian, therefore, the task of the teacher is to provide students with relevant texts to study the vocabulary minimum of the topic, thus, as a result, future doctors enrich their vocabulary with professional Ukrainian terminology.

In the formation of the competencies investigated, educational game activity proved to be one of the most effective ones, which is confirmed by its psychological and pedagogical features (freedom, competitive nature, role convention, imitation); communicative nature of the game is close to specific feature of foreign language teaching and learning as a complex discipline, for it refers to a different culture. The role play emphasizes interpersonal interaction [6], for participants "play" roles and imitate situations that are of considerable importance in real life, while the "game-based" nature of the situation frees players from the practical consequences of its resolution and their decisions, which extends the 
boundaries of selected behavior patterns, as well as it gives room for creativity., An analysis is carried out by the group members under the guidance of the teacher after the game. Thus, games are common in pedagogical practice and effective means of teaching Ukrainian language [2].

"If I was a teacher". The content of the game is the following: the teacher offers students to study the text; when the time runs out, the students should be able to ask their groupmates textbased questions, on the basis of which it is possible to check out the level of understanding the text while being in the role of a teacher.

"Competition of the connoisseurs". The group of participants is divided into two or three teams working to solve the task given. Students study additional literature, analyze and discuss the information received. Each group offers its own presentation of the topic, thus, one representative of each team takes the floor. Opponents of other teams can ask questions to find out the depth of awareness on the issue. All team members are involved in answering the questions asked.

"Detectives". The teacher prepares the text on a particular topic. Before giving it to future doctors, he / she only names the headline and invites the participants of the game to comment on the possible text-based issues. After that, the group is split into two teams; one team receives a text that lacks important concepts, without which the understanding of the content is difficult or impossible (featured words are pasted); the second team gets the full text. The members of the first team, after reading the text, can ask content-based questions, in order to be able to fill in the missing information. Discussion follows the completion of the work with an exchange of views, which gives the opportunity to investigate the issue more widely.
"Deepening the essence". Players split into two teams; each of them receives small topical texts. Team members have to distinguish the very essence of the phenomenon described, highlight the most important aspects of the information assimilated, while commenting on the topical issues. Every team presents their own views on the solution of the problem given. Then the result of the discussion is summarized, analyzed and generalized.

"Generalization". The initiator invites students to combine snippets of text on a single topic in a variety of ways. Future doctors can make notes, trying to come up with a version of a summary of these excerpts. They then tell how they combined these passages into the whole.

"Brainstorming". The teacher invites the students to solve in close cooperation with each other the following problem: "What is common and what distinguishes two certain objects or phenomena". Students read a selection of texts on a single topic and after discussion in groups of 3 to 5 people suggest solutions. The teacher writes ideas on the board, in the process of collective discussion of proposals determine the most accurate options for solving the problem.

"Ask a question". One player whispers a question and his/her partner answers the question aloud; all other participants of the game have to guess what question was asked and formulate it as precise, as it is possible. For each correctly reconstructed question player receives one point. The winner of the game is the one who scored the maximum number of points.

"Embodiment of a role". The game involves roleplaying a dialogue on the basis of a ready-made model. Students get acquainted with the dialogue-based text of a certain subject in advance and learn it, choose their roles, as well as to develop a strategy and tactics of their behavior in accordance with practical 
experience. There is also a team variant of the game: group of students is divided into two teams, each of which receives a script, in order prepare the stage performance. During the intermission, the first team states a problem, which must be solved by the second team after viewing the scene.

In the preparation of future doctors, we recommend conducting the mentioned above games during the Ukrainian language classes. The whole script must be written in Ukrainian. This approach has a double didactic effect: developing the language skills and polishing a style of communication between individuals.

The interactive nature of the activities of foreign students during the Ukrainian language classes is conditioned by the creation of learninglinguistic situations that encourage students to require foreign language communication in identical with the natural language conditions [1:26]. A language training case (LTC, languagebased close-to-reality situation) is defined as the set of language conditions necessary for a student to perform a communicative language interactions correctly and appropriately in accordance with the task given; LTCs can be constructed on the basis of the Ukrainian texts studied and viewed in close connection with the text-based exercises applied, nevertheless, they can be created outside the textual environment and incorporated into the exercises for the development of language activities. Speech situation allows to determine the relevance of speech activity on the basis of the topic studied, as well as to provide its communicative motivation, identify aspects of communication through modeling certain conditions (agree - disagree; doubt - assertion; unambiguous expression - free discussion, etc.); on the basis of the structural constituents of the speech situation

(formulation communicative tasks) in order to provide an influence that encourages communication by stimulating the intention to speak.

The content of speech in various public spheres of activity (domestic, business, educational, political, industrial, etc.) is determined by the subject of the message broadcasted. Within the framework of the solution of the issue of forming the ability of free verbal communication of foreign students, we will consider the approximate variants of situations that will be able to bring them closer to establishing contacts with native Ukrainian speakers.

1. Case of a business meeting with native speakers, closely connected with the discussion of plans of cooperative work, acceptance of obligations, making new business acquaintance, etc. The following speech intentions are possible: showing an interest in the topic of conversation; supporting the judgment of foreign-language partners on the issue discussed; expressing your own point of view; expressing disagreement with the position of the interlocutor with the intention to reject it or find a compromise solution; expressing satisfaction to the nature of the conversation and its result.

2. Situation of meeting with business partners at an exhibition or presentation of new equipment in a certain field of production, equipmentsupply tenders, various types of medication created by domestic associations and companies. We use such speech intentions as: expressing the desire to interest native speakers in the acquisition of certain exhibition objects; giving the opportunity to feel your desire for a positive result of the meeting; making an assessment of what is presented at the exhibition: offering more reasons to substantiate the one's opinion; asking at a slow pace with a possibility to repeat what has already been said; politely asking 
the meaning of words or expressions you do not know; enabling the opponents to feel firm in defending one's position in some aspects of the issue discussed; enabling one to feel your partial satisfaction with the intentions of the native speakers or to postpone the negotiations for later date; showing wiliness to finding a compromise; thanking the native speakers for their participation in the exhibition or/and presentation.

3. Case of being in foreign-speaking family. The following speech intentions indicate the wiliness and zeal for communicative: desiring to express one's admiration for the reception and hospitality of the hosts, the beauty of the home's interior and the surrounding landscape; apologizing for lack of language skills; disagreeing with some of one's mannerisms that do not conform to the language of the native speakers; expressing reaction if offended something by any of family members (peers); trying to show interest in the statements of the owners, their presentation of sights of the city; expressing reaction if one doesn't want to visit places of interest; trying to present one's homeland in the best possible way, including family, its customs and traditions; not indicating surprise by something that is important from the point of view of the owners and deserves attention; showing appropriate communicative behavior, as well as the nature of the statements, if one doesn't not share the emotional feelings of the family representatives; showing wiliness for strengthening the mutual communication in the future.

According to our point of view, the successful formation of speech competence depends largely on properly organized assessment and supervision, including the verification of results, which is a mandatory component in the learning process, and it must be performed at all stages of the educational process. Thus, assessment is of particular importance after studying a particular section of the programme and mastering its contents. The essence of verification of results of educational process is not only to identify the level of student's academic achievements, which must meet the educational standard of the respective programme, but also to determine the student's internal state and intention to succeed.

In modern pedagogy, such concepts as "assessment of knowledge", "supervision" have a broad meaning. In didactics the second concept is usually replaced by the concept of "pedagogical diagnostics". We identify the latter as a process, in which, based on the required scientific quality criteria, the teacher monitors students and conducts questionnaires or tests, processes observations and surveys, and reports the results obtained to determine success rates, describe behavior, explains their motives, or predict students' actions in the future.

Based on the analysis of theoretical sources, we have identified the following requirements for assessment: purposefulness, systematicity, representativeness.

In order make assessment purposeful, the teacher must set a specific task, considering the type, form and means of assessment he/she chooses for carrying out the supervision duties, therefore, it is done by comparing the types, forms and means with the assessed objects. The purposefulness of assessment is ensured by the clarity and orientation of all its structural components, their logical connections and interdependence.

In order to get a true picture of the results, assessment must be objective, for objectivity plays an important role in the evaluation process. If the content and techniques of assessment correspond to the nature of the 
assessed object, then it can be stated that the assessment is objective. If the teacher aims at checking the vocabulary, the object must have tasks for assessing the vocabulary.

One of the necessary requirements for assessment is its systematicity, which can be possesses the following characteristics: cycle, time factor, skill, material. In the case of a cycle, assessment is required after completing a number of classes that was required to be mastered in a specific amount of time by the students. For example, during several sessions students learn a new vocabulary units on a particular topic, work it out, write vocabulary dictations, etc., and at the final stage to assess the correctness of using this vocabulary while performing different tasks.

Regulatory role in the process of assessment belongs to the didactic principles, which are introduced in the pedagogical practice of assessment as a set of theoretical rules that facilitate the effective supervision of students' cognitive activity. The purpose of their implementation is to achieve the greatest effectiveness of assessment to improve the quality of training. At the same time, the principles of science and efficiency, hierarchical organization, objectivity, systematicity, fairness and comprehensiveness are the leading ones.

The main role belongs to the principle of science, because it is primarily determines the possibility of effective supervision. This principle requires the use of scientifically validated means of assessing students' knowledge in practice, and also requires that tests meet the certain requirements of reliability, which reflects the characteristics of the tests in terms of accuracy and robustness of measured results. Considering the student's level of knowledge as an object of measurement, there are two main groups of factors that influence the accuracy of pedagogical assessment. The first group is clearly random, for it is subject to psychological and physiological factors, influence of which on the results of assessment cannot be predicted. The second group consists of non-random factors that reflect the particularities of the measurement methods and means selected.

The principle of effectiveness involves the choice of a certain method of assessment, which ensures the full implementation of supervision functions with minimal time, effort and resources on the part of the teacher. Improving efficiency is facilitated by the fulfillment of a set of requirements, on the basis of which a search is made for the choice of the best combination of forms and methods of assessment: optimal performance of educational, learning and developmental functions of knowledge evaluation; achievement of objectivity in the process of performing the diagnostic function of knowledge validation; minimally required time and effort of teachers, providing maximum effect during the process of assessment; use of quantitative methods and reliable tests to assess students' level of readiness.

Adherence to the principle of hierarchical organization leads to a certain structural system of knowledge, skills and abilities in selecting the content of supervision. This principle is focused only on the field of practical development of measuring instruments, aims at the selection of the most important, larger requirements of standards for their further reflection in the tests. Compliance with it should be permanent on all stages. For example, this principle cannot be guided only in the process of final certification, otherwise non-certified students can undeservedly be honored for inappropriate achievements. In general, the principle of hierarchical organization directs teachers to 
systematically control the compliance of the level and quality of educational work with foreign students with the requirements and demands of educational standards.

The principle of systematic pedagogical assessment depends on the proper planning of activities. Uneven and random increases in the frequency of tests, as well as their unexpectedness provoke additional stress in students, nevertheless, reducing the number of assessment units also leads to negative consequences. Systematic monitoring is especially important in order to identify the poor learners and those not capable of steady sticking to the academic schedules and curricular requirements.

The principles of objectivity and fairness are closely interlinked, since objectivity is a prerequisite for fairness. Before deciding on the choice of methods for implementing the principles, it is necessary to form an idea of objective evaluation. The problem of objectification of grades is of particular importance in connection with the attempt to introduce the ideas of cooperation between the teacher and the students in the educational process. This is not an accidental combination, for low grades are usually perceived by students as unfair and the latter are the main causes of confrontation between the participants of the educational process. Therefore, objectification of the results of assessment can be considered necessary but not sufficient condition for establishing relations of cooperation between the teacher and the students.

The principle of comprehensiveness emphasizes the need for a careful selection of the content of assessment and validation, which should represent the one of educational work. The tasks intended for the final review must not duplicate each other, covering as much evaluated material as possible. The main focus is on testing the acquisition of basic knowledge, skills and abilities, in the same time, minor elements of insignificant importance are excluded from the final assessment process.

The connection between the assessment and quality of education plays an important role. Thus, if the evaluation is well organized, the learning outcomes will always be higher. Objective assessment creates additional incentives in the work of the teacher, encourages students to study the subject more deeply. Therefore, pedagogical validation is a means of improving the quality of learning; improving the quality of learning is inextricably linked with improving the assessment system, bringing its tools and methods to the ideas of collaboration between the teacher and the students.

In order to achieve the preset goals in the educational process in higher educational institutions, the most objective, accessible and combining advantages of all types and forms of assessment organization is, in our opinion, a module-rating system of student achievement evaluation [4: 220]. The analysis of educational practice indicates that ensuring the formation of a foreign language communicative competence and the success of learning becomes possible through the modular construction of the system of professional training of future specialists. The term "module" in the etymological sense means the compression, the arrangement of knowledge in a user-friendly form. In pedagogy, a module is considered to be a coherent block of information that contains a targeted programme of actions, scientific and methodological support that determines the achievement of the educational goal.

In modern conditions, various tools and means are used to create a modular system, thus, its features are the following: rational division of the material of the discipline into modules 
and verification of mastering the theoretical and practical content of each module; systematic evaluation of the quality of students' preparation for each practical training; use of a wider scale of knowledge assessment; encouraging systematic individual and independent work of students throughout the semester and improving the quality of their knowledge; increasing the objectivity of students' knowledge assessment; competition in training; identification and development of students' creative abilities.

\section{Conclusions and research} perspectives. Increasing the number of foreign students seeking higher education in Ukraine requires thorough training of teachers; it predetermines not only teaching professional disciplines, taking into account the level of Ukrainian language, but, above all, proper linguistic training. After all, mastering the basics of any profession begins with the acquisition of a certain amount of general and professional knowledge, as well as mastering the basic means of solving professional tasks, which provides for the proper level of formation of professionally predetermined speech. This is an important part of the professional training of specialists in all fields.

It is the use of a set of interactive teaching methods for foreign medical students that gives them the opportunity to arouse their interest in obtaining a specialty and to motivate information-creative activity in accordance with their skills and abilities. Modular-rating control of academic achievements of foreign students at a medical university is especially effective, if it is given a systemic character, and only then assessment becomes an important factor in the process of training future doctors.

\section{REFERENCES (TRANSLATED AND TRANSLITERATED)}

1. Hryshchenko, I.V. Komunikatyvni aktsenty navchannia ukrainskoi movy jak inizemnoi [Communicative accents of teaching Ukrainian as a foreign language]. Naykovi zapysky Drohobytskoho derzhavnoho pedahohichnoho universytetu im. I. Franka. Seria "Filolohichni zapysky. Movoznavstvo" Scientific notes of Drohobych state pedagogical university I. Franko. Series "Philological Sciences. Linguistics", 10, 26-28 [in Ukrainian].

2. Zinchenko, V.H. Zusman, V.H., Kirnoze, Z. I. (2008). Mezhkulturnaia kommunikatsia: ot sistemnoho podckhoda $k$ sinergeticheskoj paradigme: uchebnoie posobie [Intercultural communication: from a systematic approach to a synergistic paradigm: study guide]. Moskva: Nauka, 223. [in Russian].

3. Interaktyuni tekhnologii navchannia: teoria, dosvid. Metodychnyi posibnyk [Interactive learning technologies: theory, experience. Methodical guide] / avtory-ukladachi O. Pometun, L. Pyrozhenko. (2002). Kyiv: A.P.N., 136. [in Ukrainian].

4. Kalashchnik, N.V.

(2016).

Diahnostyka rivniv sformovanosti mizhkulturnoi komunikatyvnoi kompetentnosti inizemnykh studentivmedykiv [Diagnosis of levels of formation of intercultural communicative competence of foreign medical students]. Suchasni informatsijni tekhnologii ta innovatsijni metodyky navchannia u pidhotovtsi fakhivtsiv: metodologia, teoria, dosvid, problemy: $z b$. nauk. prats - Modern information technologies and innovative teaching methods in the training of specialists: methodology, theory, experience, problems. Kyiv-Vinnytsia, vyp. 45, 219-223. [in Ukrainian].

5. Lalak, N.V. (2011). Interatyvna model navchannia studentiv: problem ta perspektyvy [An interactive model of 
teaching students: challenges and prospects]. Naukovyi visnyk Uzhhorodskoho natsionalnoho universytetu: Seria "Pedagogika. Sotsialna robota" - Uzhorod national university scientific bulletin: Series "Pedagogy. Social Work", vyp. 20, 69-70. [in Ukrainian].

6. Sysoieva, S. (2011). Interatyuni tekhnologii navchannia doroslykh: navchalno-metodychnyi posibnyk IInteractive adult teaching technologies: educational and methodical guide]. Kyiv: EKMO, 324. [in Ukrainian].

7. Solodka, A. (2005). Polikylturne vykhovann ta osvita - krok do integratsii osvity Ukrainy $\mathrm{v}$ jedynyi zahalnokulturnyi prostir [Multicultural upbringing and education - a step towards integrating Ukraine's education into a unified cultural space]. Naukovyi visnyk Mykolaivskoho derzhavnoho universytetu: $z b$. prats - Scientific bulletin of Mykolaiv state university, 212-217. [in Ukrainian].

8. Jukalo, V.Ya. (1999). Kultura movy [Culture of language]. Ternopil: Ukrmedknyha, 77. [in Ukrainian].

Received: October 04, 2019 Accepted: November 14, 2019 